\title{
The Review and Forecast on Development History of IPR in the World
}

\author{
Xuemei An \\ School of law, Guangdong University of Financial \\ Guangdong 510521, China \\ Tel :86-20-8560-9980Ｅ-mail: anxuemei@gmail.com
}

The Work Was Supported by the Natural Science Fund Project, Serial number is: 70633003

\begin{abstract}
Intellectual property rights are private rights. Its legal regulation should apply to the general principles of private law. Since the first intellectual property system came into being in the West, humanity has passed through the course of nearly four hundred years. In the nearly four centuries of history, intellectual property rights have completed their conversion from feudal power to people's private rights. Today, it is necessary to summarize the history of intellectual property system and forecast its prospect.
\end{abstract}

Keywords: Review, Forecast, IPR, System

\section{Introduction}

Since the first intellectual property law was set up in the West, humanity had passed through the course of nearly four hundred years. In the nearly four centuries of history, intellectual property rights have completed their conversion from feudal power to people's private rights. Today, it is undeniable that the revolution brought by IPR not only has expanded the traditional content of property rights system, led to the intellectual property system become the world's most important property rights system, but also made a profound impact on mankind in the 21 st century. However, the emergence of this new system is not a straightforward process. With the development of new technologies and human cognitive ability, as an implement to balance the private rights and public interests, the intellectual property system always encounter challenge and controversy.

\section{The establishment and improvement of intellectual property system}

Intellectual property rights were a general term of human rights based on the results of their intellectual and creative production. Thus, it is a collection of concepts. It covers copyright, patents, trademarks and so on. In different countries, intellectual property rights cover a slightly different content. As a social system promoting innovation, the intellectual property system has established in the Western countries at first, and later has been constituted in the world. Walking along with its historical development, the course of intellectual property system in Western countries has gone through three main stages which called as germination stage, development and internationalization stages.

\subsection{The Germination stage of the intellectual property system}

For the intellectual property rights system, Patent law is the first system in the world. The emergence of the patent system has built an outset to human intellectual property system. At the early in 13th century, the King of Britain had granted a license to the inventors a patent. At the 15th century, the Mediterranean Sea area was filled with the winds of technological innovation in which called on the Governments to establish a new legal system to protect technology. the Republic of Venice city constituted the first world's patent law in 1474. Soon after, the wave of the industrial revolution swept through whole Europe, some country have established a national patent system. The United States even established the principle of protection of proprietary technology in the Constitution, made patent protection to the height to constitutional level.

Copyrights have the same color with a strong monarchical power. Before the birth of the copyright system, various countries have had long-standing system of printing privileges. According to this franchise system, the king can grant a printed right to license the printer rather than the copyright owners. In 1709, Britain built the first modern copyright law - "the Queen Anne Act." Followed this, the United Kingdom, France and Germany establish the copyright system respectively. Under the influence of these countries as a pioneer, the copyright system has been gradually accepted by 
Governments. Trademark is an intellectual property rights which is closely related to technology trade and trade in services. Trademarks originated in Spain. The trademark system in the modern sense began in the 19th century. In 1857, France set the first legal system to protect trade marks in world. Subsequently, the trademark system rapidly developed in the world.

\subsection{Stage of stable development}

During a long period time of that the framework of the intellectual property system which include of copyright, patent and trademark rights for the main modules has established. Many countries accepted a variety of forms of intellectual property rights in different attitude and progress. At the same time, new types of intellectual property rights have and continue to be gradually integrated into the system of intellectual property rights. All these developments demonstrate that the historical development of the intellectual property system has entered a stage of steady development. By the end of the 80 's of the twentieth century, the new wave of civil legislation began to rise. Many countries try to develop the Code of intellectual property or integrate intellectual property law into the Civil Code. These activities set off a wave of codification of intellectual property rights. Issued the first "Intellectual Property Code" which collection of all the intellectual property system, France promoted the Code of the movement to a climax.

\subsection{The international stage}

Since the late 19th century onwards, along with the high-tech development and the expansion of international trade, intellectual property transactions in the international market have also begun with the formation and development. At the same time, there were a huge contradiction between international demand for intellectual property rights and regional restrictions. In order to resolve this contradiction, some countries have signed the International Convention for the protection of intellectual property, and set up a number of global or regional international organizations. A system of international protection of intellectual property rights has set up in the world. The convention of "Paris Convention for the Protection of Industrial Property"(which established by France, Germany, Belgium, and other 10 countries launched in 1883) is the first international convention in protecting Industrial Property. "Berne Convention for the Protection of Literary and Art" is the first international convention about copyright. The foundation of International Conventions indicated that the intellectual property system had come to the international stage. Among them, adopted under the framework of the WTO in 1993, "Trade-Related Aspects of Intellectual Property Rights Agreement"(TRIPS) succeed in conclusion during developed country and developing country, which heightened the national standards of protection of intellectual property rights to a unified higher platform. The agreement provides many principles and systems to other country's legal system. And TRIPS has greatly promoted intellectual property system into the integration process.

During the process of promoting the IPR into international stage, the World Intellectual Property Organization (WIPO) and the World Trade Organization (WTO) can not be left unrecognized. WIPO was established in 1970, later became a subsidiary of United Nations specialized agencies. At the same time, WIPO was in charge of more than 20 international conventions relating to the protection of intellectual property rights. TRIPS agreement achieved the goal to link international trade with people's intellectual property rights. And the result is that it not only to expand intellectual property protection to the outside of the traditional areas of trade, but also penetrate into the technical trade and service trade, etc. all aspects of international trade ,and accelerate the international trade into a new trade pattern..

At the 21 st century, intellectual property rights system is faced with new challenges. The adverse effects of intellectual property system appear gradually. In some developing countries, the protection of IPR has brought the high cost about some medical or necessaries; the price of some product with IPR is so high that it can't meet the needs of people in trouble. The viewpoint of doubting on the intellectual property system was usual in the domestic and international. Some scholars even claim that the intellectual property system will be its end. This condition prompted people to start to reflect on their legislation about IPR in practice and theory. Similarly, since decades the implementation of TRIPS agreement has performed, many developing countries came to re-examine the impact of the national economy brought by the integration of intellectual property protection standards. At the same time, with the rapid development of biotechnology, engineering and new materials technology, society has brought a great number of problems about the intellectual property system to every country. To save these problems, developed countries have started a new round of amendments to the legislative activities of the intellectual property system. New laws and regulations continue to emerge, and the scope of intellectual property's objects has continued to grow.

In spite of this, the establishment of IPR system has become an irresistible trend. In today's world, many countries have a more full understanding of the social progress and political and economic interests from knowledge. Developed countries take its monopoly of advanced scientific knowledge as a magic weapon for technology leadership. Developing countries take the absorbing and creating knowledge as an important way to catch up with developed countries. It can be expected, the next era is not only to develop and possess social substantial resources, but also to develop and possess mortal knowledge resources. Moreover, with the deepening of global economic integration, the international process of intellectual property system will be further accelerated. Protection of intellectual property rights has not only become the necessary conditions of a country to promote for economic development, but also a 
prerequisite as the maintenance of international competitiveness.

\section{The establishment and development of Chinese intellectual property system}

Compared with foreign countries, Chinese legal construction of intellectual property rights start to later. For China, the intellectual property system is an import. However, in a short period of time, China has completed legislative achievement in IPR within less than three decades which developed countries spent the course for 300 years. It is very rare for Chinese significant legislative achievements. From a historical development, the construction of the intellectual property system in China can be divided into three stages.

The first stage is the initial phase. From the late 70 s of the last century, China started the early work to build the intellectual property system. The earliest statute law of intellectual property rights is the trademark law in 1982. The controversial legislative work is the patent system. After reform and opening up, the demand of economic development and relationship with foreign need set up a kind of system for the protection of IPR system. These requirements led to a big debate whether the patent system should be established. Until 1984, the first patent law in China was officially published. It opened up a new chapter in building intellectual property rights system in new China. In 1990, the copyright law was issued. About ten years later, the basic framework of Chinese intellectual property system has formed preliminary. The content of Intellectual property rights also has been greatly enriched.

The second stage is the integration into the international stage. From the early 90 s in 20th century to early this century, it is a well-polished period of intellectual property system in china. During this period, China has not only enacted some law to protect the computer software and other relevant legal provisions, but also revised and improved continuously the established system. Today, China has joined in a number of International Convention for intellectual property protection. China's IPR protection has been fully met the minimum standards set forth in the Convention, in some areas there even existed the circumstances of "super-international standards".

The third stage is the period of strategic initiatives. In the few years after entered to the WTO, the Chinese government attached great importance to the protection of intellectual property rights. All aspects of the project about intellectual property rights have made great progress. Intellectual property rights cause has entered a period of strategic initiatives. In 2005, the development of IPR flourished in many aspects. In January of this year, the national IPR strategy leading group composed of the State Intellectual Property Office and other departments more than 20 components was established formally. This is the intellectual property system in China has entered the strategic initiative in view of the most typical signs. In June of the same year, the institution of Chinese IPS started his work officially. National intellectual property strategies as an opportunity to take the initiative to achieve the goal of improving the intellectual property system, China began a comprehensive revision of the intellectual property system. In 2008, the National Intellectual Property Strategy Outline was established.

\section{The development and personnel training of Chinese intellectual property}

Accompanied by the establishment and improvement of intellectual property system, the personnel training and scientific research about IPR is also gradually on the right track.

At present, the specialized personnel of intellectual property rights in China is divided into four groups such as the intellectual property management personnel, the intellectual property judicial personnel, the intellectual property service personnel and the intellectual property teaching or research personnel.

The intellectual property management personnel mainly refer to the people who manage intellectual property rights within their jurisdiction staff in enterprises and institutions units or government administration. For businesses, intellectual property management work is not only related to the emergence of independent intellectual property rights, the cultivation of creative ability, but also closely related to the protection, the use and application of intellectual property. In general, the gap of intellectual property management talent in Chinese enterprises is larger. Only some high-tech enterprises have established a relatively complete body of intellectual property management. Some enterprises do not even have set up full-time management of intellectual property rights, which led to a certain extent, the low level of intellectual property management. This situation needs to improve urgently.

Intellectual property judicial personnel refer to the new expertise administration of justice personnel to ensure accurate decision and maintain the legitimate interests of intellectual property rights. At present, there are about 2,000 judges to engage in the justice work of intellectual property rights.

Intellectual Property Services personnel are mainly experts who engage in intellectual property representation, or the promotion transactions, transfers and operations of intellectual property. Increasingly competitive in the international market incentives today, the competitiveness of enterprises have not only embodied in products and capital, but also more embodied in the ability of the operating intellectual property rights. In such circumstances, the role of intellectual property services can not be ignored. In view of the desire for intellectual property professionals as well as the good prospects of trading services on intellectual property rights, the intellectual property service industry is considered as 
the sunny industry in services field.

In China, the scope of service personnel who engaged in intellectual property transactions is relatively broad, including not only patent agents, trademark agents, copyright agents, etc., also includes intellectual property lawyers. At present, there are generally more than 600 patent agencies, more than 1,500 trademark agencies. But the service personnel who engaged in copyright and technology brokerage transaction brokerage service is also rare talent.

At present, China has more than 20 universities and scientific research institutes have established specialized research or educational institutions of intellectual property, community transport a large number of high-end intellectual property professionals.

\section{Conclusion}

Review the past; China achieves great success in building the system of intellectual property rights. The work of personnel training on intellectual property rights is carrying through in full swing in every aspect. The proportion of the industrialization of intellectual property rights is improving. Intellectual property experts have been out of school gate and replenishing in all much-needed positions of the motherland. We have reason to believe that, in the concerted efforts of the Chinese government, corporate managers, academics, as well as all sectors of society, the cause of Chinese intellectual property rights will go to greater prospect.

\section{References}

Dennis S. Karjala. (2003). Distinguishing the Subject Matter between Patent and Copyright. Institute of IPR studies Working Paper. P439.

Elizabeth Armstrong. (1990). before copyright: The French Boo-Privilege System, Cambridge University Press. P1498-1526.

Eric Setliff. (2006). Copyright and Industrial Design an “Alternative Design”. London: Pall Mall Press. (Chapter 9).

Raymond Bill. (1971). The profits of ideas: Privileges in eighteenth century of France, Studies.vol.4 (2)

Roselyn Alva. (1999). In Search of Compliance with TRIPS against Counterfeiting in the Philippines: When is enough? Oxford: Hart Publishing. P453.

Stephen Stewart. (1999). Two Hundred Years of English Copyright Law, Two Hundred Years of English and American Patent, Trademark and Copyright Law, American Bar Association.

Susan K. Sell. (2003). Private Power, Public Law: The Globalization of Intellectual Property Rights, west publishing.P327. 